\title{
Retail Policies and Urban Change in Naples City Center: Challenges to Resilience and Sustainability from a Mediterranean City
}

\author{
Rosario Sommella *(D) and Libera D'Alessandro
}

check for updates

Citation: Sommella, R.;

D'Alessandro, L. Retail Policies and Urban Change in Naples City Center: Challenges to Resilience and Sustainability from a Mediterranean City. Sustainability 2021, 13, 7620. https://doi.org/10.3390/su13147620

Academic Editors:

Herculano Cachinho and

Teresa Barata-Salgueiro

Received: 30 April 2021

Accepted: 3 July 2021

Published: 7 July 2021

Publisher's Note: MDPI stays neutral with regard to jurisdictional claims in published maps and institutional affiliations.

Copyright: (c) 2021 by the authors. Licensee MDPI, Basel, Switzerland. This article is an open access article distributed under the terms and conditions of the Creative Commons Attribution (CC BY) license (https:// creativecommons.org/licenses/by/ $4.0 /)$.
Department of Human and Social Sciences, Università degli Studi di Napoli "L'Orientale", Largo San Giovanni Maggiore 30, 80134 Naples, Italy; ldalessandro@unior.it

* Correspondence: rsommella@unior.it

\begin{abstract}
Political discourses, public discussions, and studies in different fields have increasingly focused on the vulnerabilities affecting cities and on the possible responses to them, which are often traced back to urban resilience and sustainability. Research and debates in the field of retailing and consumption geographies are no exception. To carry out a critical analysis on the retail policies associated with the urban commercial change of the Naples city center, the case study is placed in the context of the literature review focusing on three concepts: spatial vulnerability, adaptive resilience, and territorialized sustainability. The analysis is conducted combining data, policy, and planning documents with long-term field research. The changing relationship between consumption practices, retail dynamics, and policies highlights a sort of hybridization of commercial and consumption central cityscapes, which is produced by the coexistence between retail-led phenomena of regeneration and forms of local resistance. The results of the research highlight, from a Mediterranean perspective, new general insights on the impact of selective forms of vulnerability and on the adaptive resilience strategies adopted, but most of all on the indispensable rethinking of the urban retail governance for the enhancement of urban livability, social cohesion, and locally sustainable lifestyles, activities, and places.
\end{abstract}

Keywords: urban retail governance; mediterranean city; spatial vulnerability; retail resilience; urban sustainability

\section{Introduction}

In writing the final part of this article, within a context still dominated by the pandemic crisis, it seems more appropriate than ever to discuss the relationship between retail, consumption, and city in light of the three interpretative keys of this special issue: vulnerability, resilience, and sustainability. The urban images of the city centers that, during total or partial lockdowns, have shown the closing of retail and leisure activities, together with the consequential lack of people who normally walked, purchased, and consumed there, have had a sort of shocking effect. This effect was perceived in different times and dimensions: both during the week and on the weekends, both according the subjective and individual perceptions of citizens and the collective awareness of groups who meet up in those areas of consumption. For some, the image of the empty city centers has aroused an almost nostalgic return to newly appreciate these "liberated" spaces. For others, it has created a sort of longing even for the phenomena connected to the transformation of these spaces into retail, consumption, and tourism-led hubs, emphasizing in both cases their connection to some form of public urban life.

To some form because over time, actually, the characteristics of social life in public spaces have changed, above all in city centers made more homogeneous by the proliferation of similar leisure and entertainment activities and by standardized shopping and consumption experiences. Even if the current situation is temporary and connected to an 
unprecedented crisis, it seems to have accelerated processes that exert a profound impact (both material and symbolic) not only on standardized retail formats but also on the small urban retail still diversified and connected to living, working, and daily consumption spaces. It is indeed evident-not only to experts but also to those who experience the city, especially in the center and even more so as inhabitants-that the loss of the forms and functions of some traditional retail spaces began some time ago.

This contribution utilizes as a theoretical point of reference the branch of geographical studies that-from different points of view, which have been developed at diverse latitudes [1] —has focused on the previously overlooked retailing and consumption geographies $[2,3]$. Suffice it to mention two disciplinary perspectives: retail geography, which, "from being one of the most under-theorized and 'boring of fields', has come to occupy a central position within social-scientific research" [4,5]; and geography of consumption, because "by studying sites of consumption, the role of consumption in commodity chains and networks, and the function of consumer practice in shaping sociality and identity, geographers have also provided important insights into the operation of power" [6]. The rediscovery of these two sub-disciplines has also given life to innovative areas of study, such as new retail geography $[7,8]$ or to further generations of studies, such as new consumption geographies [9] or even, with specific regard to the city, to researches on the "mutual and dynamic relation between urban development and consumption" [10]. In addition to these, the opportunity to draw on long-term studies focused on Mediterranean Europe and Latin America, which have contributed to research progress on these topics from geographical and cultural contexts apart from those dominant, has been relevant for developing the investigation on our case study [11].

In the spirit of this journal, our contribution is also placed in a current state of research field that has focused on vulnerability, which is particularly evident in some retail areas of the city center, and on possible solutions to this, varyingly traced back to resilient and sustainable goals. Nevertheless, while many political discourses, public debates, and academic studies have been devoted to analyzing the different vulnerabilities affecting urban systems, the role that consumption practices and commercial dynamics plays in these processes is still scarcely explored, especially in some territorial contexts. In the same way, while studies on governance aimed at enhancing city resilience and sustainability have gained much attention, very few emphasize the potential of urban retail policies. This, despite the new relationship between urban regeneration, retail, and consumption poses new challenges both to the three notions-from the conceptual and the empirical point of view-and to policies inspired to them.

\section{Research Stages and Methodology}

The main purpose of this article is to develop a critical analysis on the local retail policies associated with the urban commercial change of Naples city center through the interpretative key of the geographies of retail and consumption. Although rooted in a specific context, the reflections developed from a Mediterranean perspective on the implications of the new relationship between dynamics and policies can offer useful lessons. Local and diverse declinations of the same concepts and planning, deconstructing unifying narratives and actions, by combining economic and cultural variables, can provide useful tools for new responses to the conceptual and practical questions posed by the current urban commercial change.

Firstly, in order to reach this objective, the analysis has been framed in the mentioned field of studies with particular reference to vulnerability, resilience, and sustainability. After a brief introduction on the role and the usefulness generally acquired by the concepts within different disciplinary fields, the literature review on the topics through the lens of retail and consumption geography is used to support the conceptual discussion. In view of the case study, this has been oriented to outline specific declinations of the three concepts: spatial vulnerability, adaptive resilience, and territorialized sustainability (Section 2). 
While grounding the first notion in the broader context of the urban vulnerabilitiessuch as environmental, social, and economic-we specifically focus on those factors that challenge the vitality, viability, and vibrancy of the city centers. Among these, our empirical research has underlined the influence of suburban commerce, of e-commerce, of new retail formats and entertainment activities, thus investigating the effects of the socioeconomic crisis, and recently, the first impact of the pandemic. The perspective of a spatially differentiated vulnerability has allowed us to explain, even from an operational point of view, the selective dynamics that connote the diverse impacts produced in the central areas of Naples both by the processes of retail decline and disintegration of the urban commercial fabric so as by new adaptive phenomena and forms of revitalization.

Even more so in the case of resilience, we have emphasized the growing interest for this flexible concept and its utility with regard to some city issues, such as mobility, quality of life, or urban systems capable of transcending crises and shocks by leveraging on local resources. In this last perspective, retail resilience and, above all, adaptive resilience have been individuated as the two key elements of the analytical framework. In particular, the dynamic and multidimensional nature of the adaptive resilience has enabled us to connect its theoretical relevance with an empirical application in the analysis of local urban commercial policies and dynamics. It has been considered as a sort of yardstick to assess the lack or very low effectiveness of the retail policies implemented at the scale of Naples city center (natural shopping centers, interventions for the protection and support of historic shops, etc.), in terms of reorientation of forms and functions of the central urban retail systems, but it has been also used as a conceptual and empirical tool to verify the existence or not of local and embedded adaptation strategies (of commercial activities, retailers, consumers) in response to the commercial pressures.

The close links between urban resilience and sustainability in the municipal policies planned in our context above all in the last ten years led us even to verify the usefulness of applying the principles and guidelines of sustainable development in the study of city center changes, examining the role that retail can play in these processes. Associating the city sustainability with the preservation of diversified urban commercial systems to respond effectively to the needs, wants, and desires of different kinds of consumers [12], our case study led us to refer to a "territorialized" sustainability. This can be understood as an alternative path aimed at combining sustainable goals with historical specificities and local milieux, which are in part still original and hybrid. With specific regard to the issues of this article, the reference is to a sort of hybridization, particularly evident in some Mediterranean cities, of commercial and consumption central landscapes. Although forms of hybridization are naturally evident in all urban spaces, including those in which the diversity resulted from mixing local and global is even more evident, these cities seem to show different case-specific cityscapes that are worth studying. Their hybrid cityscapes are one of the effects produced by the interaction between persistent forms of resistance of local specificities and spontaneous phenomena or even urban policies inspired to global processes of urban competition, city branding, and commodification of the city, which since the 1990s have been pursued also by many Southern European cities [13].

Secondly, the research is indeed briefly framed in a Mediterranean perspective, that is to say developed on the basis of studies placed in the framework of the Mediterranean city debate. The urban commercial analysis on transformations of the Naples city center is conducted, trying to deconstruct certain narratives, thanks to the results of an empirical research that highlights the coexistence between homogenizing retail-led phenomena of regeneration and a strong local embeddedness based on the commercial features of uniqueness and specificity (Section 3).

Thirdly, in view of the case study, a conclusive discussion is developed on the selective forms of vulnerability that exert a different impact at the local scale and on the adaptive resilient strategies adopted, but most of all on the indispensable rethinking of the urban retail governance (Section 4). In our opinion, policies inspired by a minimization of the environmental impact of leisure and retail activities and, at the same time, aimed 
at ensuring social inclusion by satisfying the needs of all the consumers and capable of preserving the diversity and complexity of the city commercial fabric can play an important role in the new forms of urban planning.

Our reflections are supported by almost twenty years of multiscale analysis on the relationship between the city, retail, and consumption. Therefore, the materials used are the fruit of an analysis that depends on the collection, over several years, of available data (mostly census data) and on a policy documents analysis (normative plans and programs elaborated at various local scales). Notwithstanding leveraging on a profound knowledge of the economic, social, and physical dynamics of the central commercial areas, these materials have a limited significance to understand the impact of most of the recent retail and consumption changes in a context such as the Neapolitan. This consideration has still rendered necessary the accompaniment of the cited sources with others coming from gray literature and from media, but the research has mainly been enriched through the continuous confront with the fieldwork. The latter has been indispensable to update the composition and characteristics of the commercial fabric and, thanks to the use of qualitative methodologies, it has been constantly supported by the observation of retail areas in different times of day, including night-time and weekends, without ignoring daily life. The consolidated knowledge of the city and thus the possibility of counting on both formal and informal channels in order to carry out in-depth interviews with those who have been identified as privileged observers [14] have been fundamental elements in the analysis of paradigmatic locations chosen on a case-by-case basis for empirical research. Similarly, as the interpretive prism has been shifted by the retail-city relationship to integrate the role of consumption, the interviews of retailers and stakeholders have been enriched by those with consumers. The research experience in the central areas of the city began in 2004 and has been marked by various stages through the years $(2006,2008-2009,2011$, 2013-2014, 2016), the last during the two-year period of 2018-2019 on the occasion of a Research Project of Relevant National Interest (Italian acronym PRIN), focused on the topic Retail, Consumption, and the City: Practices, Planning and Governance for Urban Inclusion, Resilience, and Sustainability [15-17].

Attention not only to spectacular consumption, but also to an ordinary one [18] in the ordinary cities, even thanks to the comparison with research developed in other contexts, can offer new insights from a Mediterranean perspective. Cities worldwide are indeed exposed, as the current situation shows, to increasingly complex challenges that encourage reconsidering the different vulnerabilities affecting the urban retail systems at the local scale. In turn, this reconsideration can be useful to examine the more or less resilient strategies adopted which, precisely because of their diverse embeddedness in different local contexts, can contribute to planning new policies for the enhancement of urban livability, social cohesion, and for the development of sustainable lifestyles, activities, and places.

\section{Theoretical Background and Conceptual Discussion}

A series of phenomena encourage focusing attention on current retail and consumption geographies in urban centers, which are the parts of the city that seem to have undergone the most visible and severe effects of change: from the globalization of retail to the changes of commercial function at the local scale, from the forms of urban regeneration diversely connected to the advent of new formats to the changes in consumption patterns and lifestyles, and again to the effects induced by the economic crisis, by the e-commerce boom, and, more recently, by the pandemic. The profound transformations that preceded the latter, rather than revitalizing the role of city centers as public, community, and livable areas for the city's inhabitants, had already emphasized their characteristics of spaces "for use and consumption" of the various kinds "of users and consumers" of a $24 \mathrm{~h}$ city in pursuit of new types of appeal. Having an attractive city center has been the goal of many urban measures, strategies, and policies, alongside a material and symbolic transformation of the city [19] which has found in retail and consumption two key drivers. 
The consequences of these phenomena on urban and social contexts are not less pervasive where, as in the case of Mediterranean cities, the urban fabrics in the recent past were profoundly connected to social diversity, to mixed uses of the land, and to a milieu in which commerce has uninterruptedly constituted a fundamental component. Looking at the cities of Mediterranean Europe, the urban commercial cityscapes have drastically changed, especially because of the most recent transformations inspired by the same competitive pressure and by the same pursuit of postmodern forms of retail and consumption that have characterized other cities, in Europe and beyond. In many cases, urban governance has rapidly turned toward city design, selective local interventions, forms of communicative planning, and urban décor for tourism and hypermobile international capital [20].

Within this framework, the much more complex relationship between retail and the city has not taken on the same connotations everywhere but is profoundly differentiated in the different local contexts. To interpret this new relationship in Naples, "strong" versions of dominating concepts or passepartout interpretations founded on experiences matured in hegemonic contexts do not seem adequate. Notwithstanding, as we will show, the city is facing phenomena that produced undeniable effects on the spatial organization of retail and on the reorganization of cityscapes characterized by new interactions between consumption and the demand for places [21]. These phenomena, rearticulating mainstream logic at a local scale, can contribute to a more efficient comprehension of central retail and consumption cityscapes connoted by an increasing complexity.

The challenges faced by the retail city relationship have been amplified by the consequences of the so-called retail revolution, which is further accelerated by globalization processes affecting retail. With the former, reference is usually made to the radical innovations that led "toward larger scale economies in all areas of retailing" and to "the introduction of new specific large stores" [22], which produced a spatial restructuring of the organizational logic and of the models of retail localization. These innovations are often understood as a series of dichotomic contrasts: in Italy, "natural" / planned shopping centers but, also in other local contexts, small/large stores, traditional activities/innovative formats, centers/suburbs. These last three pairs of dichotomies are often associated with each other with many consequences, even on an interpretive level. The polarization between small traditional retail in urban centers and large innovative formats outside the cities has often been misleading even because, as emphasized by Findlay and Spark, "much retail activity still takes place in local centers, local high streets and parades and other often overlooked locations", leading people to take for granted the retail changes that have marked their evolution [23].

Returning to retail globalization, according to the analysis by Coe and Wrigley, it is characterized by two interrelated aspects: the globalization of sourcing by large and powerful retailers and the role played by leading transnational retailers in the international expansion of the store networks [24]. After an intense period of expansion (mid 1990s-mid 2000s), due to the global economic and financial crisis, according the two authors the process underwent a reorganization and a consequent reassessment of its logic and practices. This has shaped consumption dynamics at both national and local scales, even though the latter are still mostly unexplored in studies on this topic. Even if underestimated in the near past, the change in lifestyles and mobility and, with this, the change in consumption models and practices has also significantly influenced what we can define as an actual process of "rescaling of retail". This is a reconfiguration of the territorial retail scales, which has been accompanied by what Coe and Wrigley define as a complex mosaic of forms of regulation, de-regulation and re-regulation. In the Italian context, this rescaling of retail can be effectively interpreted through a multiscale analysis of European, national, and local policies [25].

The spatial change of retail appears, in this sense, particularly interesting to analyze at the urban scale, where it often overlaps with processes of regeneration, which are in part fruit of the competition between cities. In terms of the attempts to revitalize spaces in decline, the processes of city branding and the policies founded on place-based approaches, 
combining the augmented mobility and the growing fortune of the urban tourist industry [26], both in global and ordinary cities have relied on an increasing involvement of retail, leisure, and consumption activities. However, in terms of recent phenomena of retail decline, which very often represent only the most visible aspect of processes of urban crisis, the pandemic has also come to the fore. Just as it occurred due to the effect of the economic crisis and the impact of the technological revolution, from the point of view of retail, this event has already begun to make some areas more vulnerable than others, risking contributing to their further marginalization.

\subsection{Vulnerability}

The literature has focused on the notion not only from a conceptual point of view, that is to say to vulnerability theory and thinking, but also on the different vulnerabilities, first of all environmental and socio-economic, which currently affect the urban systems. To make evocative examples, suffice it to mention some illustrative case studies: in the field of spatial planning, measuring vulnerability has been sometimes considered as the first step for resilience, e.g., building a GIS environment to deliver maps of climate and risk vulnerabilities [27]. More in general, the research has been focused on environmental hazards, for example with regard to global warming which, in recent decades, has made cities increasingly vulnerable with dramatic consequences and enormous costs [28]. Again, much attention has been paid to measure the different vulnerabilities to which cities are generally exposed through social, economic, and natural indicators.

In the light of the case study, the reference is to vulnerability more as a result of spatial processes, because of the theoretical and operational value for our research. While it is still partially connected to factors that, in the past, determined decline and even the death of retail areas, today must be considered in new terms. On one hand, in fact, several factors continue to exert their impact, such as those mentioned by Barata Salgueiro and Cachinho citing a work on the development of inter-urban retail areas in the beginning of the 1970s by Berry [29]. The author defined four components of what he called "commercial blight": economic, frictional, functional, and physical [30]. Although more than 50 years old, this conceptualization has been considered attractive for the internal logic underlying the portrayal of factors related to the retail blight and for offering "a holistic approach to managing retail decline and coordinating policies at the local level" [31]. These factors have changed and today must be considered alongside others: social, cultural, and also related to the growing importance of retail management and of technological change linked to e-commerce.

An illustrative example linking spatial vulnerability to the case study can help to understand both the meaning of the concept and its operational use for our research. In the Naples city center, many of the cited factors of vulnerability continue to have a significant impact, though according to selective spatial dynamics. In some cases, they have produced a progressive and rapid substitution of activities, so much so that they even threaten the survival of anchor stores on main streets or on main retail areas, as well as that of some "neighborhood" stores; in other cases, places affected by factors usually considered as tending toward decline, while touched by some phenomena of vulnerability, have revealed surprising capabilities of resilience. The latter have leveraged on a retail offer so embedded in the urban fabric to meet the needs of a large segment of disadvantaged consumers [32] made up, in the Neapolitan context, by diverse groups of the urban population.

The concept of spatial vulnerability with specifically regard to retail, according to Fernandes and Charmusca [33], is fundamental in order to understand that of resilience: in this perspective, urban planning that aims toward the reduction of the risk of vulnerability and the collapse of a system (to be intended as a single store or an entire retail area) should focus on resources and strategies able to allow systems to move beyond such crises, continuing to satisfy the basic needs of consumers and carry out their functions in a sustainable manner. The paradox lies in the fact that, as Cachinho states, urban commercial systems have never been vulnerable, and sustainability has never been so 
threatened as it has in recent times [34]. In our fieldwork research in Naples, both retailers and consumers have referenced different vulnerabilities which, in their opinion, have contributed to threatening the cohesion of the of the urban retail fabric, accelerating and amplifying episodes of commercial decline.

\subsection{Resilience}

As emphasized by some scholars, the notion of resilience-generally used to designate the ability to contend with situations of change and uncertainty-has substituted those of vulnerability and sustainability as a recurring concept in political and academic discourse and thus become a guiding principle in planning and development. Weichselgartner and Kelman trace back its rebirth to the ability to cross disciplines and to find itself at the junction between political science and practice [35]. Today, it is applied in various fields, including geography, where-according to the two scholars-vulnerability and resilience are seen sometimes as opposites and sometimes as two sides of the same coin but, in most cases, they are considered as connected by a non-linear relationship [35] (p. 253).

Browsing the conference programs on spatial planning in Europe, in 2013, Stumpp had already defined resilience as the "the new buzzword in urban-regional matters" [36]. Recently, it has become crucial in the analysis of territorial contexts during the health crisis and in terms of thoughts on post-pandemic cities. The aim of such contributions is not returning to "normal" but creating better and more resilient urban societies, sometimes relaunching models developed before the crisis, such as those on urban mobility and quality of life. Amongst them, one can recall the 15-min city (in which everything the residents need can be found within $15 \mathrm{~min}$, without motorized transport), revised incorporating four dimensions: density, proximity, diversity, and digitalization. Moreno et al. have connected this model to the 15-min Walkable Neighborhood and the 20-Minute City Model, as well as to chrono-urbanism and new forms of urban planning [37].

Examining the notion through the lens of this article, the potential unlocked by retail resilience is great and has been developed above all since the economic crisis of 2007-2009. With specific reference to urban retail systems, Barata Salgueiro defined it as "the ability of different types of retailing, at different scales, to adapt to changes, crises or shock that challenge the system's equilibrium, without failing to perform its functions in a sustainable way" [38]. More recently, Barata Salgueiro and Guimarães have revised various contributions and recalled that the concept roots lie in the ecological, socio-ecological, and psychological perspectives [39]. Retracing the distinction between engineering resilience, ecological resilience, and adaptive resilience, they have remembered that the latter is close to the evolutionist approaches in regional economy, geography, and other social sciences. This has been also considered a new theoretical frame in order to analyze the forms of vulnerability in retail systems and the possible answers to these. The last approach, according to Dolega and Celiñska-Janowicz, points research toward resilient paths that do not aim to chase an impossible return to a pre-crisis past, while concentrating on the aptitude of a system to uphold long-term development and resist against various shocks through the ability to adapt and reconfigure its structure in the long term [40].

As Wrigley and Dolega did previously [41], they refer to the dynamic and multidimensional concept of adaptive resilience not only from a theoretical perspective but also from its practical applications regarding spatial and urban planning. From this point of view, there are various operational connections with the objective of our investigation. In the case of Naples the prism of adaptive resilience has allowed distinguishing different strategies of varying success, sometimes mediated by local actions and interventions but more often put in practice by actors such as those effectively defined as "local retail heroes" [41] (p. 2360). In Naples city center, these heroes are retailers who have been able to take advantage of local identity and of endogenous factors to sustainably upgrade and locally "adapt" products, activities, and retail locations to the consumption changes or to the most recent crisis. To what point these policies and strategies can be transformed in a real and overall "resilient" reconfiguration of the urban retail structure of the city center as a whole and to 
what point they remain simply "ordinary" and occasionally responses to shocks are issues that retail resilience discourses and practices have to deal with.

\subsection{Sustainability}

Before the rediscovery of the concept of resilience, the formulation of the political paradigm of sustainability represented a significant turning point in the way in which the economy and environment, to be analyzed in light of the new relationship between growth and development and associated with ethics, have been intended.

The adoption of sustainable development policies has undoubtedly been a strategic factor for cities, especially the Mediterranean, in which "the specific resources, strong points of local systems in global competition, are made up mainly of an extraordinary environmental and cultural capital" [42]. In this contribution, twenty years ago, we proposed to adopt, for the Mediterranean cities, a "territorialized" sustainability, which in the regional context meant avoiding the temptation to apply a model of sustainable development based on predetermined standards. Our attempt was to discuss what at the time was proposed as the unifying notion of city sustainability, recalling the diverse declinations it could assume in relation to the different trajectories of urban development at the Mediterranean scale. A few years earlier and in much broader terms, relevant studies in urban geography had deconstructed unifying narratives on the relationship between urbanization and industrial revolution through the development of the Mediterranean city thesis [43]. The perspective of the territorialized sustainability, close to the discussed versions of vulnerability and resilience, allowed identifying alternative paths in order to combine sustainable development goals with historical specificities that have traces of the man-environment relationship on the Mediterranean coasts and, therefore, with local milieux still original and hybrid.

Returning to the relevance taken on by the paradigm, also in relation to commerce the sustainability goals have become indispensable targets, especially in the light of the described retail globalization process. In making an assessment of the future agendas of retail geographies in 2009, Wrigley explained that for Western economies it was almost a mandatory direction because this was produced by the same evolutions of retail and of the consumers' consciousness [44]. Sustainability has been applied to retail even with specific reference to the urban scale. Associating it with the conservation of diversified retail systems able to efficiently respond to different types of consumers, Erkip underlines how "urban sustainability requires the viability and vitality of the city center, part of which involves the resilience of different kinds of retailers" [12] (p. 330, our emphasis). The reference to these two drivers of the urban policies offers several points of reflections at the Mediterranean scale. Beyond the rhetorical traps that lay below the two concepts of resilience and sustainability, the connection between their theoretical and operational dimensions is strictly case-specific.

\section{Consumption Practices, Retail Policies, and Urban Commercial Dynamics in the City Center of a Mediterranean City}

Viability and vitality, intended today as increasingly connected to resilient and sustainable goals, recall many of the traditional elements considered in the recent past founding of the Mediterranean milieux: street life, the so-called piazza culture [45], the role of public spaces, retail streets with strong cultural heritage, a city center made up of economic activities, residences, culture, and leisure spaces. Some of these elements have become central to the forms and functions of the post-Fordist city, especially with the increasing competition between the urban spaces. This has often brought processes of commodification of the city, which have been in turn accompanied by city marketing and city branding strategies, so as of neoliberal governance, in many cases setting off imitative processes of the Mediterranean cityscapes efficiently defined by Leontidou as "a world-wide Mediterraneanisation of inner city landscape" [46].

Despite being the sources of imitative practices, many cities of Mediterranean Europe have experimented some severe consequences of these processes in socio-economic and 
environmental terms, especially where they have intersected with other phenomena. The economic crisis and the related austerity policies [47], mixed with weak governance and new forms of planning at the urban-regional scale, in many of these cities have indeed exerted a profound impact on the built environment and on the daily life of citizens. The acceleration of urban regeneration has often generated conflicts between residents, entrepreneurs, and various types of users (global tourists, commuters, metropolitan consumers), especially at the city-center scales. Two key words seem to sum up the policies and dynamics which in recent years have characterized the urban trajectories of many of these cities: "authenticity", researched spasmodically or re-invented in order to increase attractiveness, and "hybridization" of the cityscapes [48].

Obviously, Mediterranean urban spaces that are peripheral or semi-peripheral, in many cases, have not been touched by said changes, or they have been touched in a different manner. Even looking at the most recent transformations through the lens of retail and consumption geographies, not all phenomena that have passed through city centers can be interpreted through the same categories or through rigid models. This does not mean that the effects of the transformations of the cities caused by globalization and tourism even in these contexts have been brought forth by a change. Connected to modifications in retail offering in order to respond to a new demand for products, places, and times above all in the center, these changes have often produced unknown forms of socio-spatial polarization and of disintegration of the urban retail fabric or have given life to new retailscapes [34] (p. 133) characterized by the coexistence, almost seamless, between forms of homogenization and resistance of local specificities.

This last seem to be the case of Naples, which is a peripheral city at the worldwide scale with a strong international image and a significant cultural heritage. As a result of the specificities of touristification, foodification, and gentrification, we cannot analyze the literature on these topics and the urban impact of global tourism, as evidenced by the growing role of short-term rentals and food in some Neapolitan central spaces. On one hand, there are various connections between these phenomena and the changing central retail areas, especially at the scale of streets, piazzas, and neighborhoods, which have experimented episodes of regeneration connected to the thematization of their retailscapes. On the other hand, these phenomena seem to have developed so quickly as in a nonuniform manner, within a fragmented context that is difficult to read, attributing the label of touristified, gentrified or foodified to the whole city center. In a local context such as that of Naples, spontaneous or guided episodes of retail regeneration have still not produced the pervasive consequences generated in other urban spaces but are rather geared toward forms of coexistence between increasing phenomena of retail thematization and a still diversified consumption-oriented economy.

\subsection{Urban Retail Change in Naples City Center}

Naples is the center of a vast and populous metropolitan area. The city is also the capital of the Metropolitan City (Città Metropolitana), which is a local territorial body regulated at the Italian scale by the national law 56/2014. Compared to other metropolitan cities in 2016, Naples was third (after Rome and Milan) for number of inhabitants and first for population density; it had the highest percentage of young people and population of working age (15-65 years) [49]. However, the city showed a less active demographic trend as compared to the recent past.

Made up of 30 neighborhoods in 10 municipalities, according to the data of the permanent census carried about by the National Institute of Statistics (Italian acronym Istat), Naples in 2019 had 949,000 inhabitants. The central areas, which host most of the foreign population, show diverse situations. Of the 16 neighborhoods that make up either fully or in part the areas of the UNESCO Historical Center Project (Red Zone and Buffer Zone), there have been slight signs of growth only in a few cases. Notwithstanding, the II Municipality, whose neighborhoods are fully part of the aforementioned areas, with about 20,000 inhabitants/square kilometer is the most densely populated in the entire city. 
In considering the conceptual discussion, it seems interesting here to refer to the first Urbes Report, which is designed to offer an overall picture of fair and sustainable well-being in Italian cities. The Urbes report on Naples, in 2013, dedicated a detailed part to the retail network as a factor of urban quality. The extensive network was considered an element connected to livability, safety, and sustainability, above all for the disadvantaged consumers who could not easily access large retailers, which were mostly associated with the elderly population. Compared to the national scenario, the report certified the exceptional resistance of the commercial activities on the regional and provincial territory (where the latter coincided with the aforementioned Metropolitan City) and, above all, on the territory of the city of Naples. The reference was mainly to the "sustainability of Italian neighborhood retail activities", which in the Neapolitan context, as well as in the whole Campania region, showed a substantial stability if compared to the decline in the rest of the country [50]. Six years later, in 2019, Campania still stood out at the national scale for being the Italian region that hosted the highest number of retail shops (16.59 for 1000 inhabitants), and for having also the greatest territorial density of wholesale activities (7.1 for 1000 inhabitants) [51].

The reference of the report to large retailers was due to the growth, in the metropolitan capital during the previous thirty years, of large and medium-sized retail companies. In line with the characteristics assumed by the phenomenon in Southern Italy, the growth was considered delayed but progressive [52]. Meanwhile, in many parts of the metropolitan space, the presence of these companies has become so cumbersome that it contributed to processes of retail suburbanization; the increasing importance taken on by these formats is to be considered also within the city of Naples. Here, the diffusion of retail chains has regarded the peripheral areas and, according to what was established by the Municipal Plan for Retail Activities, the spaces left empty by ex-industrial areas, where formats of larger dimensions have been located. However, the diffusion of this retail typology has characterized also the central areas, especially for that regard the medium-sized food distribution, which is efficiently defined as a sort of "new proximity retail" [53]. From the data of the National Retail Observatory on the geographic division of the new retail distribution, the Neapolitan capital has registered a sustained increase, from 2010 [54] to 2019 [51], in the number of department stores, but it has also experienced a significant rise in supermarkets and minimarkets (Table 1).

The widespread distribution of these last formats in the central areas of Naples has developed in the context of a rapid turnover, which is related to what we have stated as to the globalization of retail and its variation in host countries.

The relationship between commercial activities and urban spaces has profoundly changed at the scale of the center and has been also deeply affected by policies, which have in turn changed the face of the historical core. The decade of the 1990s has been the key moment for changes that have affected this part of the city. It must be remembered that, in the previous decades, the urban retail fabric had slowly fallen apart due to a series of phenomena: the progressive loss of the close connection between retail and artisan craft production; episodes of decay, neglect, and abandonment of many squares and retail streets; a decrease of residents in favor of other categories of inhabitants and users; an increase in crime and illegality; the gradual disappearance of shops that were symbolic in terms of cultural heritage; forms of downwards standardization of supply and demand; the inability to offer a "sustainable" response to new demands in consumer, leisure, and entertainment spaces; the gradual disappearance of connections between retail form, function, and the identity of the city. 
Table 1. Supermarkets, minimarkets, and department stores in Naples as the capital city 2010-2019 (sales area in square metres).

\begin{tabular}{cccccc}
\hline \multicolumn{5}{c}{2010} & \multicolumn{2}{c}{2019} & 2010-2019 \\
\hline Sales area & Employees & Sales area & Employees & Sales area & Employees \\
\hline 47,110 & 988 & 67,044 & 1424 & 42.3 & 44.1 \\
\hline Establishments & Franchising & Establishments & Franchising & Establishments & Franchising \\
\hline 76 & 0 & 98 & 0 & 28.9 & 0 \\
\hline Sales area & Employees & Sales area & Employees & Sales area & Employees \\
\hline 20,904 & 493 & 32,465 & 765 & 55.3 & 55.2 \\
\hline Establishments & Franchising & Establishments & Franchising & Establishments & Franchising \\
\hline 74 & 0 & 114 & 0 & 54,1 & 0 \\
\hline Sales area & Employees & Sales area & Employees & Sales area & Employees \\
\hline 16,021 & 159 & 35,283 & 572 & 120.2 & 259.7 \\
\hline Establishments & Franchising & Establishments & Franchising & Establishments & Franchising \\
\hline 8 & 1 & 28 & 1 & 250 & 0 \\
\hline Source: authors (2021) on Ministry of Economic Development, 2010; 2019. &
\end{tabular}

In the first half of the 1990s, the turning point was marked by very significant urban actions: the pedestrianization of some important retail streets, the liberation of piazzas from cars, and the returning, along with parts of the city that held important traces of cultural heritage, of public spaces to the citizens. In 1999, the increase in size of the city center was established by a specific form of planning destined to the historic center (as to the eastern and northwestern zones), the so-called variants to the city planning scheme ("Master Plan"- Piano Regolatore Generale) [55]. The "Historical Center Variant" considered historical everything built before the Second World War, while not many changes were made until the new development plan ("Master Plan of the City of Naples"-Piano Regolatore Generale della città di Napoli) of 2004, which extended the perimeter of the historic center to include an area of 1700 acres, making the inner city of Naples the most extensive in Europe [56,57].

Returning to the 1990s, the significant extension of the historical center was carried out alongside a series of initiatives that aimed toward urban renewal, starting with early stages of international branding processes that attracted tourists from Italy and abroad and were also characterized by the participation of many components of the urban population [58]. The transformative era was marked by material and discursive practices so powerful in terms of image that the period was labeled the "Neapolitan Renaissance". Urban interventions, such as revitalization of spaces, streets, and squares furniture, some pioneering forms of beautification of the historical center and the relaunching of city image had immediate effects on the valorization of retail areas, which the Neapolitans claimed and the visitors began frequenting also as spaces to consume [59,60]. In 1995, the historical center of Naples (or rather the part identified in the previous plan of 1972), was inserted in the UNESCO World Heritage list.

The reclaimed urban image, after just a few years, was nevertheless dominated by negative phenomena, bringing the city to the fore as an urban space symbolized by dualisms and contradictions that had already characterized it in the past [61]. In the first decade of the 21st century, Naples was in fact associated with the refuse crisis and the forms of territorial control of crime world. These, actually, had never disappeared, but they had 
once again become visible due to the presence of micro-criminality, which is often carried out by young, and sometimes very young, people even in central areas.

However, a new phase began with the advent of the second decade of the 21st century: the improvement in intra-urban mobility and new political choices relaunched the attractive potential of the city, which also benefitted from the unfavorable situation of other Mediterranean destinations, beginning to attract tourists again. During that period, the historical center was involved in several forms of planning, amongst which the UNESCO historical center project, launched in 2012. As pointed out in the preparatory work, the so-called "Strategic Guidance Document" (Documento di Orientamento Strategico), the goal was not only to renew the built-up area of a historical center of 980 ha $(8.4 \%$ of the municipal territory), surrounded by a buffer zone of 426 ha. The much more ambitious aim was that of intervening in the building and urban fabric, and also in the environmental, economic, and social fabric, referring specifically to goals regarding sustainable development [62].

Even in this phase, alongside plans and projects for the center, there were interventions regarding urban design and pedestrianization: the most symbolic was that of the part of the waterfront called "freed waterfront"-lungomare liberato. These interventions have been framed in a policy efficiently defined as a mix of environmentalism and "light" liberalization which in turn produced further forms of laissez faire [63], leaving great space to private actors and to spontaneous phenomena of thematization, as well as to further urban policies of spectacularization, of the city center [64].

\subsection{Results of Empirical Research}

The frame described in the previous paragraph represents the context in which our empirical investigation is placed, which aimed at testing the elements of the analytical framework emphasized in the conceptual discussion to answer to our research questions and hypothesis.

Firstly, we individuate the main local retail policies, verifying if and how they have influenced the trajectories of the urban retail systems in the city center; secondly, we verify the existence or not of interrelations between retail and urban policies more affecting the central cityscapes of commerce and consumption; thirdly, we cross-reference the analysis of these policies with the results of fieldwork on the urban commercial change of some central spaces. The aim of the fieldwork conducted in the selected spaces, paradigmatic for the retail-city relationship, has been to verify the existence or not of connections between urban retail planning, the changing commercial fabric, and the consumption practices induced both by planning and spontaneous phenomena. However, the more general aim underlining these specific research questions has been to analyze the implications and consequences of these issues in terms of vulnerability, resilience, and sustainability.

In the already mentioned Urbes report, at the municipal scale, the dense and permanent retail network was retraced to the presence of "typical village marketplaces". These areas were labeled, not without rhetorical emphasis, as emblematic places for the coexistence between retail entrepreneurs with fixed stores and market operators on public land, so as for the diffusion of the so-called natural shopping centers (in Italian Centro Commerciale Naturale-acronym CCN) [50]. We do not deal with public markets because their analysis would have required a broadening of the theoretical framework (e.g., on the dialectic between marginality/centrality) and because Neapolitan retail markets still appear as commercial places "suspended" between forms of degradation and traditional rehabilitation [65], thus requiring specific conceptual discussion and empirical researches, for which we will postpone further analysis to future investigation.

For the first point cited in the report, suffice it to recall the aforementioned Strategic Guidance Document of the UNESCO historical center project. As to retail specifically, the document refers to recuperating the connection between commerce and artisan craft, underlining the importance of the "vocations" of the central areas. Just mentioning the results of our first research on the most representative street of the city, via Toledo [66], on 
the coexistence between retailers of fixed store and market operators on the public street, the document geared toward achieving sustainable development objectives encouraging the maintenance of the forms of interaction between various types of retail: in permanent locations, itinerant, etc. [67].

For the second point emphasized in the Urbes report, according to the interpretative key of this article, the retail places and activities best suited to examining the relationship between dynamics and policies are represented by the areas and shops which are a direct expression of local planning: Natural Shopping Centers (the mentioned CCNs), Centuryold businesses, and Historic shops. The presence of the three kinds of retail places and businesses actually reveals the limited and possibly untimely policies dedicated specifically to the sector, in the context of an urban retail governance that has mostly "adapted" itself to strategies and norms elaborated at European, national, and regional scale [25] (p. 74) (Figure 1). If not for a few exceptions, retail policies seem to run parallel to urban policies, while many connections should relate the former to the latter.

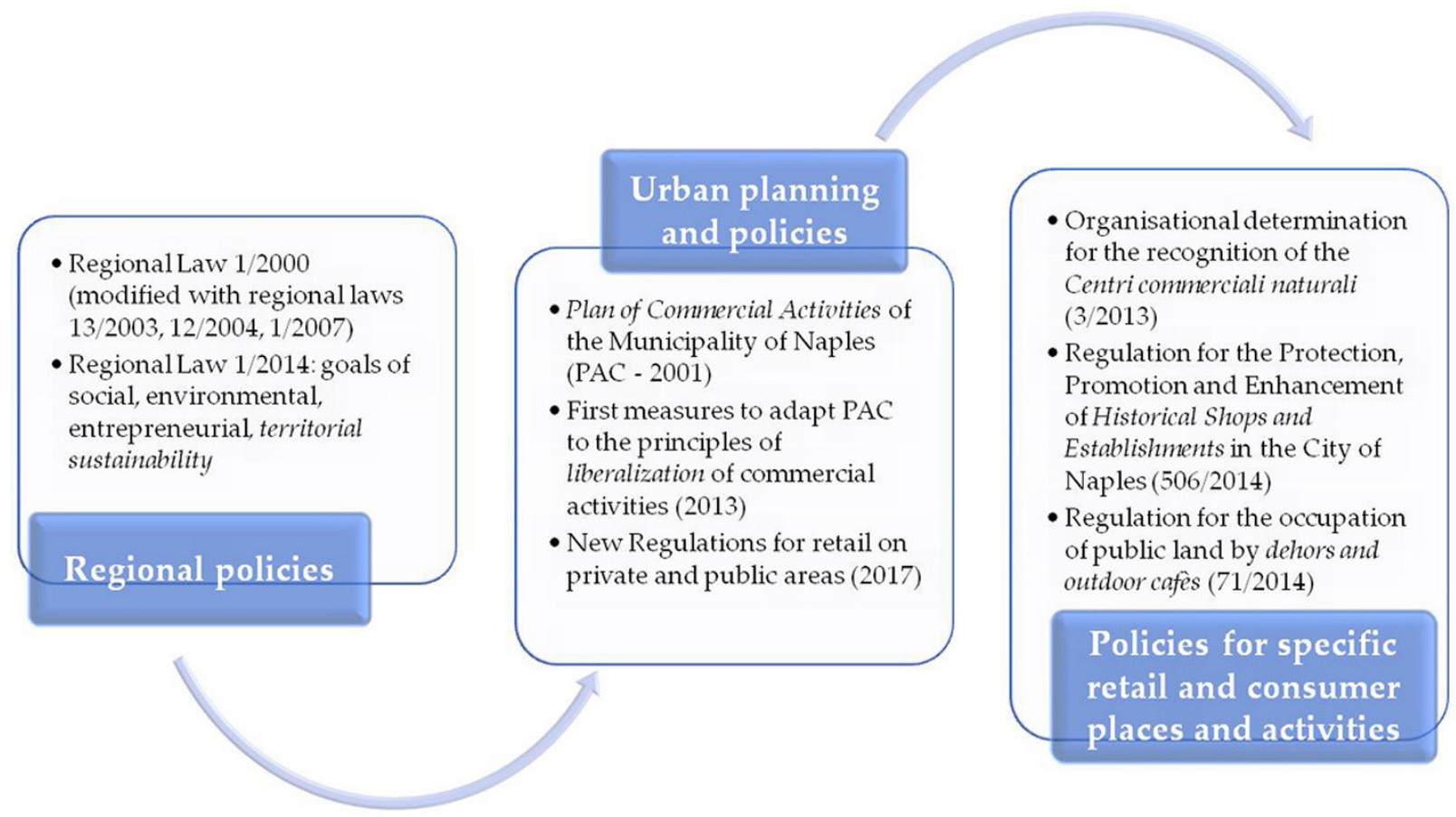

Figure 1. Main retail policies and planning at the regional and urban scale. Source: Authors (2021).

The innovative mix of selective urban actions and a laissez-faire approach aimed toward satisfying different needs (of private actors, of social movements, of citizen associations), without strategically planning forms of harmonization amongst the "new demands for places" [21] (p. 14), in the fragmented and complex Neapolitan context has produced inevitable consequences, especially in central retail and consumption cityscapes. Even if not guided by forms of speculation and financing that have, even in other Southern European cities, led to pervasive interventions in large parts of the centers, the transformation has mixed, firstly, with new retail and leisure spaces created by new entrepreneurs at the fore. These actors, often pioneers or new arrivals, have utilized formal and informal mechanisms connected to a commerce often defined as a "sponge sector", which is a term used in the past mainly to define the role of small and traditional retail, where those expelled from the industrial sector found comfort. Secondly, the urban change has mixed with the new consumption practices put in place by various types of consumactors [34] (p. 133), who are continuously less interested in products and more interested in places, as well as continuously less interested in filling their needs and more interested in experiences and desires [68]. 
As to the themes of this article, the most visible phenomena in the urban retail systems of the city center are the following: the multiplication of retail activities, often managed by young people, that aim toward intercepting the increasing appeal of food; the proliferation of fast-fashion; the liberalization that has in turn generated the diffusion, in certain areas, of dehors and outdoor cafés; the numerous leisure and entertainment activities that aim to satisfy the increasing demand coming, especially during the evening and the weekend, from the large young population that lives in the city and the metropolitan hinterland [69]; the forms of non-daily commerce aiming at intercepting the needs and desires of various kinds of users or new inhabitants. These phenomena, unregulated by new forms of governance and not dialoguing with retail presence regulated by sector policies, have produced further fragmenting of the cityscapes. It is possible to represent in a summative image the main retail, leisure, and entertainment places, located in the part of the city center included in the UNESCO project that has shown the most significant changes for these topics. The map represents even the mentioned commercial activities regulated by the policies and the areas of intervention, according to the guidelines for the occupation of public land by outdoor activities, which are aimed at a "sustainable and urban regeneration" of the Naples historic center within the perimeter of the world heritage site (Figure 2). The city center has been further expanded in the final version of the map on-site boundaries: the areas of the UNESCO historic center and its buffer zone have been respectively extended to 1021 ha and to 1350 ha [70].
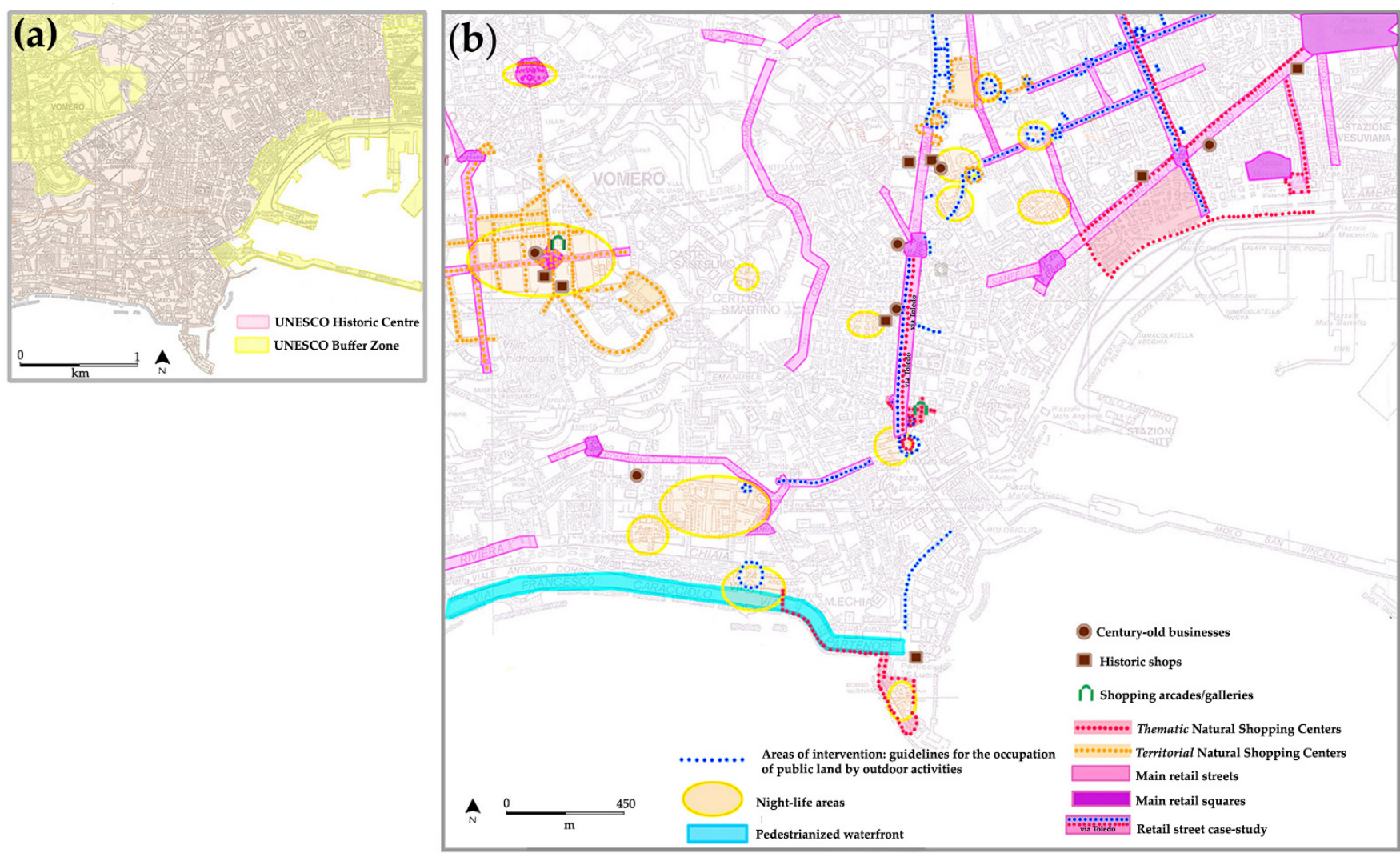

Figure 2. (a) The research area within the UNESCO historic center and buffer zone boundaries; (b) Main retail, consumption and leisure places, commercial activities, and areas of intervention. Source: (a) Authors (2021) on Comune di Napoli, Map on the "boundary of the Historical Center of Naples"; (b) Authors (2021) on [21] and further surveys (2020-2021).

In reflecting on the areas drawn on the map as the result of policies (not including the municipal markets for the aforementioned specificity with respect to our conceptual discussion), it is possible to affirm that the superimposition of retail regulations has not allowed actions for the relaunching of the city center in a sustainable and resilient manner. The eight natural shopping centers (CCNs) recognized in the whole city, four thematic and 
four territorial, especially in the center reflect many of the critical issues regarding the CCN instrument at the Italian scale [71]. This has been conceived as an outline of regeneration founded on public-private partnerships, which have been created as an answer to the desertification of the center. In the cases of "success", it has implemented small and occasional interventions on the urban retail fabric or limited territorial marketing strategies for relaunching the commercial areas and, in the worst, has resulted in a substantial inactivity.

The CCNs recognized in the Naples city center, while located in areas that were historically strategic in terms of retail vocation and showing in some cases a certain vivacity of the retailers associations, are not the result of stable and active partnerships. The implemented forms of cooperation have not been able to encourage, between public bodies and private entrepreneurs, long-term strategies of local development, using retail as a real tool for territorial renewal. The strategies of Neapolitan CCNs have not relied on city center management schemes similar to those implemented in other worldwide cities (Town Center Management, Business Improvement Districts, Centros Comerciales Abiertos etc.) which, while giving greater momentum to city branding aimed toward repositioning the central areas, sometimes have sacrificed the retail areas as public spaces. The fact that these actions in the Naples city center have not produced negative consequences experienced elsewhere does not prevent us from making some considerations. When a substantial amount of inaction has not condemned these retail areas to complete immobility, the presence of the CCNs within the territory has mostly developed into interventions of urban furniture, décor, and cleaning, generally during festivities or small-scale events. Even when the $\mathrm{CCN}$ has been able to give life to a dialogue between public and private actors in the retail field, this has not guaranteed long-term forms of virtuous collaboration. Such is the case of via Toledo. In the most well-known retail street of the city, the dialogue between the municipal administration and retailers has encouraged one of the first areas of urban pedestrianization and has also set in motion a series of improvements, but only occasionally and not as part of an overall strategy geared toward revitalizing the relationship between commerce and the city.

Retail partnerships have not been used as an instrument for implementing measures in order to protect significant commercial companies or relevant commercial areas of the center against shocks and crisis. The lack of a real preservation strategy is particularly evident in the cases of historical shops that represent a true piece of urban heritage, especially if one considers retail through a dual perspective, cultural and economic. This has guided, in terms of methods, our long-term empirical investigation on commercial activities and places, starting from the assumption that only a combination of economic and cultural variables can enable to understand processes of change in retail and consumption geographies that, in the Naples city center, have been as sudden as complex. The historical retail presences have been regulated at the regional scale-and, therefore, at the municipal one-only in 2014, through the recognition of two types of establishments: the Century-old businesses and the Historical shops (the latter defined as "spaces of historical relevance, art workshops, and workshops regarding ancient professions of historical relevance"). The 20 shops registered up in the city until today (nine century-old businesses and 11 historical shops), operating in sectors of "traditional" retail or commercial artisan areas, do not include all the shops with history still existing in the city. This testifies to the incompetency of this specific policy to identify the need to protect and safeguard retail shops and retailers, which are inevitably strictly connected to the streets and squares where the shops are located and the retailers operate. It must also be specified that, before the regulation was adopted in the Neapolitan context, many stores that needed to be safeguarded were closed for different reasons. The incapability to reconcile the need for capitalization (rather than the simple protection) of the commercial activities, which had to be intended as local resources because they were representative of a part of city cultural heritage and of a significant piece of the urban fabric, with the "stories of life and work" of retailers operating for generations in the city center has resulted in many cases according to the empirical research. 
The update of the results showed a tendency toward closing the premises located in the city center, after the most recent health crisis, even in cases of shops with a long history of embeddedness in the central fabric. This is the case of a menswear historical shop located in via Toledo (Figure 3). It seems very interesting, as a sort of answer to our research questions, to quote here the owner's statement to the local edition of an Italian newspaper:

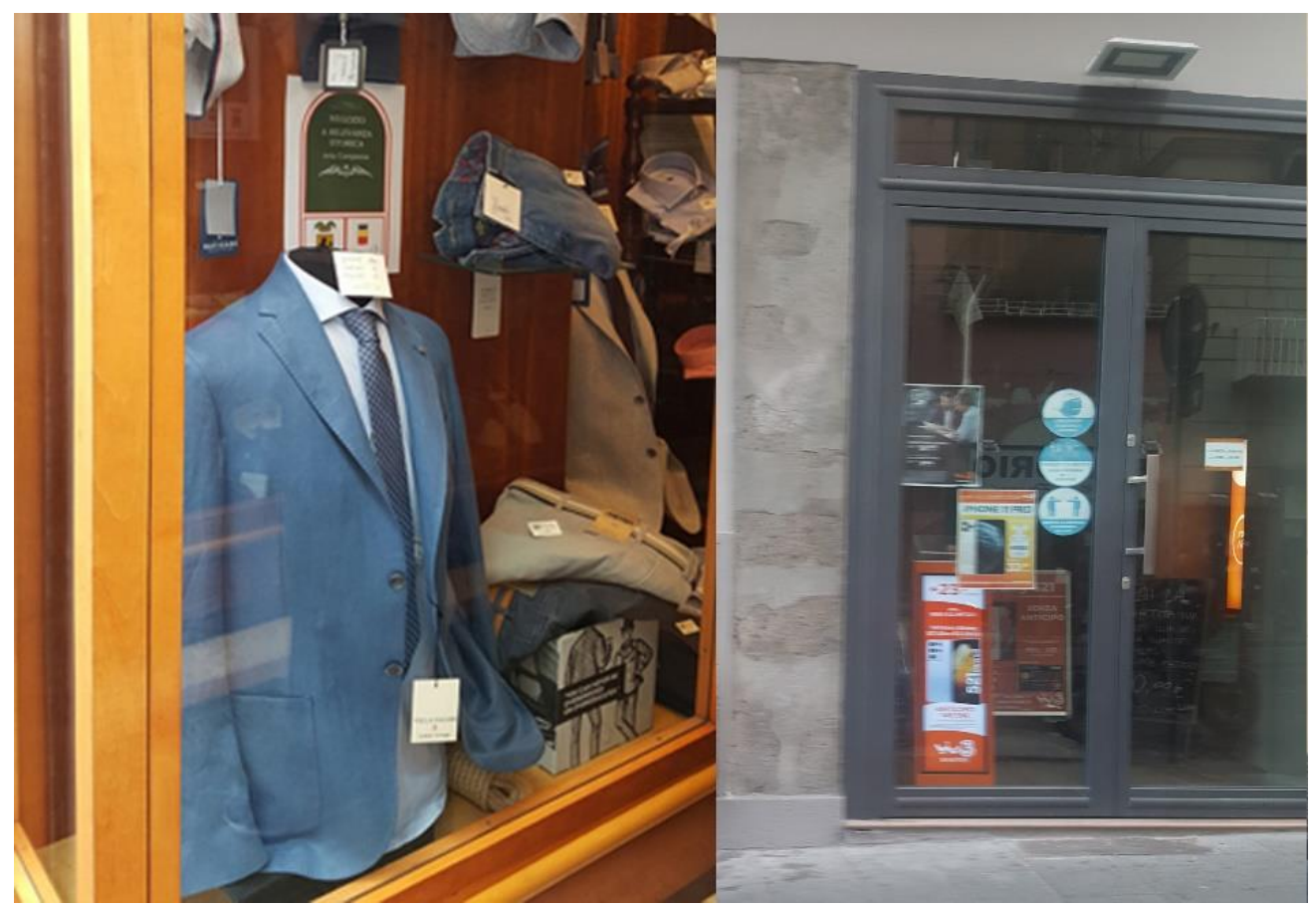

(a)

(b)

Figure 3. (a) Menswear shop located in via Toledo since 1935, with the green sign as "historic shop of Campania region"; (b) The shop substituted by a telephone store. Source: Authors (May 2020; April 2021).

"After 85 years in business, after two generations of trading in quality clothing, the time has unfortunately come for us to close down. We would like to thank our customers.... the representatives...the companies...who have ensured the success of our business over the years, so much so that we have been awarded the regional and municipal certificate of a shop of historical interest...." [72]

The opinions expressed over the years by retailers, stakeholders, and consumers were fundamental in our understanding not only the scarce incisiveness of policies for retail and the lack of ability to combine the latter with the policies of urban renewal but even more in general the distance between policies, actual retail dynamics, and changing consumer practices. As illustrative example of this evidence is derived from the in-depth investigation conducted precisely on via Toledo but in a different section from the one where the historic shop of the photo was located. A long-term knowledge of the street, together with qualitative practices of observation, surveys, and interviews, allowed us to update the retail street case study [66] (p. 213). The first reference is to the results of the field research carried out after 14 years (2005-2019) during our mentioned national research [73]. Via Toledo is currently the street that has the longest historical tradition from the commercial point of view, without comparison not only in Naples, but also throughout Italy, if one considers its international notoriety that began in the 1800s. It can be recalled as the most paradigmatic of the whole city in terms of the urban retail change, also because it is still the most frequented: for pedestrian traffic, as we have emphasized in our research in 2019, it has been classified as the tenth shopping street in Europe and the first in Italy. The investigation was updated not only through the analysis of retail facilities but also 
thanks to 100 interviews with retailers (including the in-depth interviews carried out with the presidents of commercial associations) and consumers (inhabitants, national and international tourists, and users coming from other areas of the city and the surrounding metropolitan areas) [73] (p. 304).

From the point of view of the retail structure, the perception of the change in supply is much higher than the real change. Although in the context of a similar universe of shops (103 in 2005 as compared to 105 in 2019), the retail street shows the disappearance of some clothing shops, which have been substituted with perfume and cosmetics shops, food and drink venues and activities, and footwear (Figure 4). Well beyond the numbers of replaced shops, via Toledo is perceived as the most symbolic street in terms of an urban retail change that, in the words both of the retailers and of the consumers, "takes on the connotations of an irreversible transformation". While this change is welcomed by some, others recall both the disappearance of shops present for hundreds of years on the street as well as of the department stores which, in the 1960s and 1970s, had renewed its centrality.

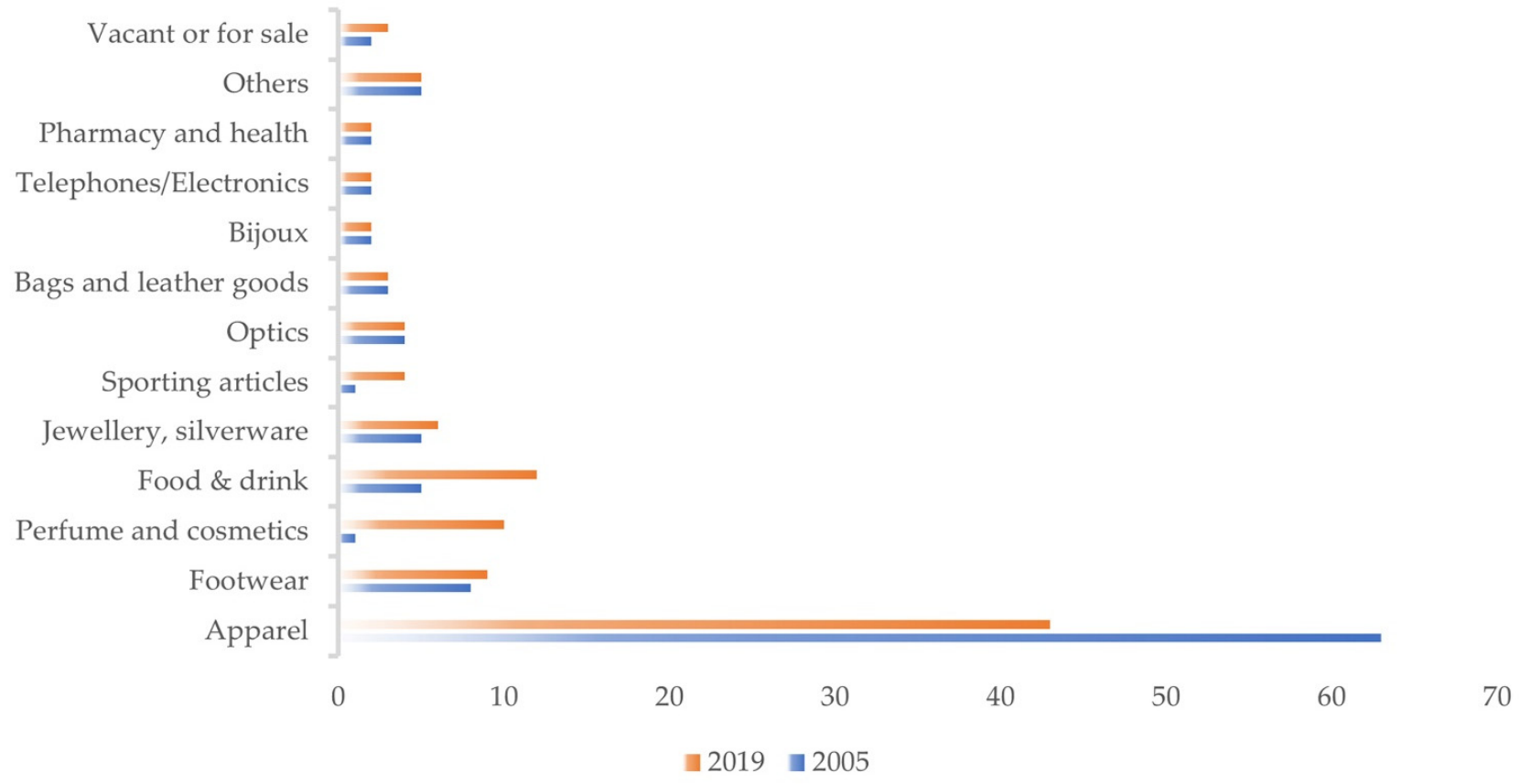

Figure 4. Evolution of the commercial fabric of via Toledo. Source: Authors (2021) on the results of fieldworks 2005-2019 [73].

In addition to the lack of shops considered to be at one with the street, its buildings, and its urban fabric, the main phenomenon cited is the "sudden and indisputable colonization of food venues and fast-fashion". The interviewers have in many cases underlined the pervasive visibility of the companies belonging to these two sectors. Regarding the first, the reference has been mainly to the greater permeability between the inside and the outside of the activities, especially in the case of street food (takeout, friggitorie, pizzetterie, and ice cream shops). In the second case, the reference has been to the entertainment factors in the signs and symbols of the brands, which are particularly evident inside and especially outside on the occasions of the events that mark the shop presence on the street. The distance between the change and the relative perceptions is more likely to be attributed to the overall urban changes which have recently affected via Toledo rather than only to areal retail transformation [73] (p. 308).

The research carried out during the fourteen years between the first and the second empirical investigation and our further updates over the last two years allowed us to draw some conclusions in this sense. Firstly, the presence of distinctive micro-geographies at the local scale [74] has diminished, especially those in which historical shops lived alongside innovative formats: there are few remaining examples of the coexistence of old and new activities (Figure 5). In this regard, many of today's phenomena, while being 
recently accelerated, have their roots in the previous decades, especially in the 1990s, when there were the first signs of urban transformation after decades of crisis in the city center: from the gradual disappearance of historical shops to the progressive appearance of stores connected to various types of brands. Secondly, many of the phenomena described seem actually mainly due to an unregulated and chaotic retail and consumption change. The almost inexistence of connections between these changes and retail policies, so as between them and the urban interventions has also prevented, in such a paradigmatic commercial hub, a real recovery of the relationship between retail activities and urban space, which is however still partially alive at the scale of some parts of the street and its surrounding areas. Thus, via Toledo can be considered representative of the mentioned retailscapes, rendered complex and diversified by more recent transformations that still present evident traces of hybridization.

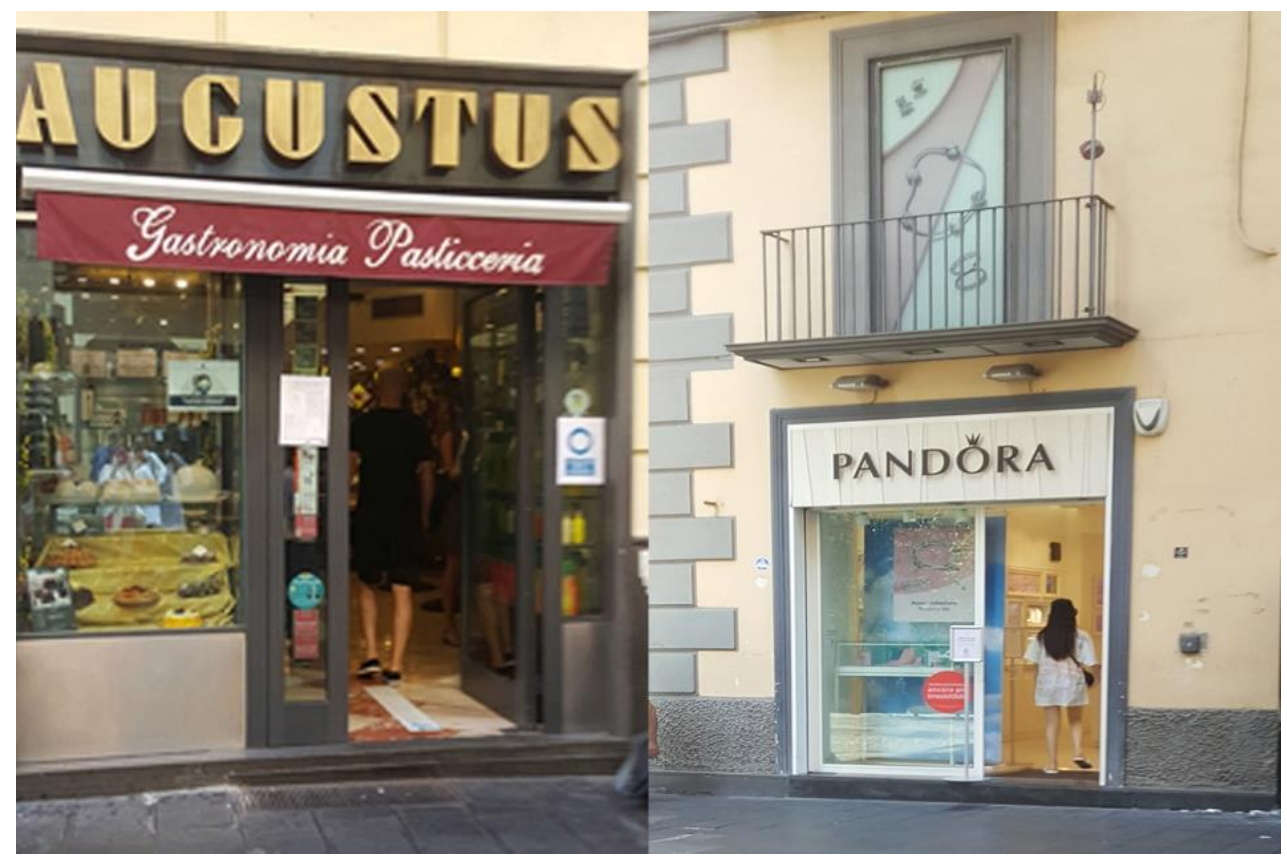

(a)

(b)

Figure 5. (a) Dairy opened in via Toledo in 1923, becoming a pastry shop, delicatessen, and snack bar in 1971; (b) The Danish giant Pandora's first Neapolitan concept store in via Toledo (opened in 2013). Source: Authors (via Toledo shops after the first Italian lockdown, June 2020).

In fact, the street is not characterized by phenomena of real retail displacement. It is, as a retail location, still a point of reference for various types of consumers (in terms of age, income, class) and, as a public space, still the object of claiming-reclaiming by various social groups, with all of the contradictions that this implies. On one hand, the shoppingscape of via Toledo is characterized by forms of modernization, particularly visible in the mechanisms of fast-fashion agglomeration similar to those described in other Southern European urban spaces, as in Lisbon [75]. However, on the other hand, it is characterized by different forms of appropriation, such as during the events that have the street as a public space of reference for instances of protest, and by forms of retail/retailers resistance. One illustrative example of the last strategy, which is particularly symbolic for a sort of ability to substitute retail policies, resulted on the occasion of the mentioned national research of 2019 [73] from an interview with the owner of a clothing shop active for more than one hundred years on that street, which even in this case represents a sort of answer to our research questions. The interviewee explained how he created a sort of small museum in different parts of his shop, showing some original furniture from other historical shops in via Toledo that have since closed, so that he could keep their memory alive. 
"I gave new life to the old chairs from a tailor's shop, using them as a clothes stand in the dressing rooms; [ ... ] there was a long, thick, wooden counter from a clothing shop where fabrics were unrolled and it is now where I put my merchandise; $[\ldots]$ there was a trunk that came from a store that sold gloves, and now it is where I display my products".

The lack of a real urban retail governance in the Neapolitan case almost seems to become a way to support a bottom-up urban change. This evidence, which emerged in different moments of the empirical research, highlights the ability to intercept through these bottom-up practices the needs and desires of various components of the urban population, such as those of an elderly population increased in many neighborhoods or of a large group of very active young users. While this has allowing the unfolding, through a very adaptive local commercial activities and retailers, of various responses to changes in taste, lifestyle, and crisis, these spontaneous phenomena are clearly not able to assure a long-term local development, preserving the urban commercial fabric and guaranteeing social inclusion, city resilience, and sustainability.

\section{Discussion and Conclusions}

Throughout the article, we have shown the current theoretical-methodological and empirical-operational importance of the three key concepts of this special issue underlining how, faced with increasing forms of vulnerability in contemporary cities, resilience and sustainability have taken on a more and more crucial role in global, European, and local agendas. In this regard, Naples is not an exception. Beyond the rhetorical emphasis inherent to these issues in local planning, the complexity of the more recent urban commercial changes has encouraged us to revisit the theoretical background in order to construct our research hypothesis and to develop the conceptual discussion in the light of the case study. The main aim was to propose, from a Mediterranean perspective, a critical interpretation of the retail policies associated with the urban commercial change in the Naples city center, identifying the forms of spatial vulnerability as well as the main challenges for retail resilience and sustainability.

Firstly, we outlined the transformation of the city-retail-consumption relationship, rapidly going over the geographical studies on these three topics, which are then nourished by their dialogue with other social sciences.

Secondly, it has been highlighted how the theoretical-empirical investigation on the Neapolitan fabric, particularly in the city center, leads to considering specific versions of the three key concepts used to build the analytical framework. If looked through the magnifying glass of retail and consumption, the forms of spatial vulnerability do not affect the central areas of the city homogeneously. Different forms of fragility characterize, in a different manner, both the areas marked by forms of commercial modernization as well as those that are marginal, where "traditional" retail is more common. This vulnerability has become even more differentiated and selective not only because of the recent urban change but also, as the analysis of the case study showed through the actions and the measures that have focused on the historical center since the 1990s, because commercial change has not found an adequate response in the retail policies. Beyond being often characterized by weakness and fragmentation, as in many other cases at the Italian scale, in the Neapolitan context these policies were not based on a real harmonization of the policies for the city and those for retail including the increasing role played by consumption, but they have been rather limited to adopt sectorial measures.

The evolutionist interpretation proposed by the adaptive resilience is well suited to analyze the complex problems that have recently challenged the resilience of urban retail systems in the Neapolitan center: from the impact of retail suburbanization to e-commerce, from the economic crisis to the most recent health crisis in which we are still immersed. Adaptive resilience has allowed for the observation of adaptation strategies-based on the skills of retailers or on the new practices of consumers-that have emerged from the empirical investigation sometimes also beyond the policies. 
This evidence highlights how, from a urban retail point of view, the Naples city center can more efficiently direct itself toward forms of territorialized sustainability. The capabilities of what can be called as the "other retail areas" in the center to respond to the consumption demand of residents and groups of disadvantaged consumers, who suffered more than others from the impact of the aforementioned phenomena, have impeded further forms of marginalization. In the meantime, this process has widened the divide between these areas and those more characterized by commercial modernization, which has been often mixed with forms of urban regeneration. The renewal is often accompanied by an improvement of the physical environment and of the public spaces, so as by the creation of new ambience and atmosphere in stores and in the areas in which they are located [76]. This often makes these areas not only more attractive but also more accessible and safer than they were in a recent past, when they remained in a state of decay and abandonment. In most cases, the processes linked to the requalification of commerce and places have not induced a real retail gentrification - which is a conceptualization that nevertheless needs to be discussed [77]—or segregation or displacement processes.

Notwithstanding, the paradox lies in the fact that this urban renewal leverages on post-modern forms of retail and consumption for recuperating the link with city identity but - precisely because of the recall to authenticity, uniqueness, and typicality - it seems to threaten the traditional connection between the historical fabric, its shops, and its inhabitants. A complex issue, if observed through the interpretative key of retail and consumption geographies, is that of the urban identity, which various individuals and groups claim and reclaim time after time. The forms of power regarding space expressed by these forms of claiming-reclaiming are carried out in the Neapolitan context by different actors and urban populations also through practices of consumption of products, places, and times which generate inevitable disputes, above all in the most symbolic central spaces, as in the case of via Toledo.

Thirdly, the focus of our case study within the framework of the critical literature on the urban spaces of the Mediterranean region and, especially, of Southern Europe allowed us to verify that in the central areas of Naples, the pursuit of the consumptionoriented economy appears to be a result of various factors: tension between pressure "from below" and spot interventions from above; forms of "glocalization" of retail and consumption; diversification in terms of the inhabitants and consumers; homogenizing retail-led phenomena of regeneration mixed with a strong local embeddedness based on the commercial features of uniqueness and specificity; new formal and informal entertainment spaces that seem to have come out of nowhere to chase the sudden tourism boom. All these factors regard the relationship between processes, actors, and projects, whose unifying characteristic seems to be fragmentation and chaos.

The case-specific hybridization of retail and consumption cityscapes, while it still is the fruit of processes that seem for the moment quite different from those experienced elsewhere, raises similar questions in terms of future challenges to socially unsustainable urban life. From this point of view, the enhancement of urban livability and the development of local and sustainable lifestyles, retail places, and activities cannot be separated from the goals of cohesion and social inclusion. It is precisely with these problems that the directions of future research must measure themselves, still considering the most recent reflection induced by the pandemic crisis.

The chance to debate these topics seems fundamental, because this is a moment in which the prejudices that often accompany the analyses on retail and consumption appear to give way to a more lucid analysis of their already acquired centrality and, therefore, to the necessity to reconsider the dynamics and policies that characterize them. On one hand, the state of retail and consumption at the time of COVID-19 shows that, despite the growth of e-commerce and of the retail spaces "outside the city", some commercial areas in the center are still emblematic in their vitality and, therefore, they are still indispensable for the life of the city itself. The mechanisms of adaptive resilience analyzed in some urban retail systems of inner Naples seem to depend on a continuous capability to fit 
and resist that, often from the bottom, in the central areas has allowed for the creation of diversified retail strategies, which in many cases have guaranteed being able to meet the needs of many categories of consumers. How much this can turn, in the near future, into the realization of truly sustainable strategies depends on the integration between these capabilities of adaptation and public policies able to guarantee, at the same time, commercial innovations, social inclusion, and an active preservation of the diversified and complex urban retail fabric.

Author Contributions: Both authors contributed equally to all parts of the article. All authors have read and agreed to the published version of the manuscript.

Funding: This work was supported by Research Project of Significant National Interest (Italian acronym PRIN), announcement 2015, entitled Retail, Consumption, and Cities: Practices, Planning and Governance for Urban Inclusion, Resilience, and Sustainability. (Dipartimento di Scienze Umane e Sociali, Università di Napoli “L'Orientale).

Conflicts of Interest: The authors declare no conflict of interest.

\section{References}

1. Carreras, C.; D’Alessandro, L. Un repertorio bibliografico su commercio, consumo e città. In Commercio, Consumo e Città. Quaderno di Lavoro; Viganoni, L., Ed.; Franco Angeli: Milan, Italy, 2017; pp. 27-69.

2. Crewe, L. Geographies of retailing and consumption: Markets in motion. Prog. Hum. Geogr. 2003, 27, 352-362. [CrossRef]

3. Mansvelt, J. Consumption Geographies: Turns or Intersections. In Encounters and Engagements between Economic and Cultural Geography; Warf, B., Ed.; Springer: Dordrecht, The Netherlands, 2012; Volume 104, pp. 47-64. [CrossRef]

4. Crewe, L. Geographies of retailing and consumption. Prog. Hum. Geogr. 2000, 24, 275-290. [CrossRef]

5. Blomley, N. I'd like to dress her all over: Masculinity, power and retail space. In Retailing, Consumption and Capital; Wrigley, N., Lowe, M., Eds.; Harlow: Longman, UK, 1996; p. 256.

6. Mansvelt, J. Consumption. In International Encyclopedia of Geography: People, the Earth, Environment and Technology; Richardson, D., Castree, N., Goodchild, M.F., Kobayashi, A., Liu, W., Marston, R.A., Eds.; Wiley-Blackwell: Hoboken, NJ, USA, 2017. [CrossRef]

7. Wrigley, N.; Lowe, M. Retailing, Consumption and Capital: Towards the New Retail Geography; Harlow: Longman, UK, 1996.

8. Wrigley, N.; Lowe, M. Reading Retail: A Geographical Perspective on Retailing and Consumption Spaces; Arnold Publishers: London, $\mathrm{UK}, 2002$.

9. Lane, R.; Mansvelt, J. New consumption geographies: Introduction to the special section. Geogr. Res. 2020, 58, 207-213. [CrossRef]

10. Jayne, M. Cities and Consumption; Routledge: London, UK, 2006.

11. Barata-Salgueiro, T.; Cachinho, H.; Guimarães, P. Introdução. In Comércio, Consumo E Governança Urbana; Barata-Salgueiro, T., Cachinho, H., Guimarães, P., Eds.; Centro de Estudos Geográficos, Universidade de Lisboa: Lisbon, Portugal, $2020 ;$ p. 7. [CrossRef]

12. Erkip, F.; Kızılgün, Ö.; Mugan, G. The role of retailing in urban sustainability: The Turkish case. Eur. Urban Reg. Stud. 2012, 20, 329-342. [CrossRef]

13. Leontidou, L. Beyond the Borders of Mediterranean Cities: The Mediterranean City in Transition. ISIG J. Q. Int. Sociol. 2009, 18, 131-140.

14. D'Alessandro, L.; Sommella, R. La ricerca sul campo: Brevi riflessioni ed esperienze. In «Dentro» $i$ Luoghi. Riflessioni ed Esperienze di Ricerca sul Campo; Lisi, R.A., Marengo, M., Eds.; Pacini: Pisa, Italy, 2009; p. 60.

15. Viganoni, L. Commercio, Consumo e città. Quaderno di Lavoro; Franco Angeli: Milan, Italy, 2017.

16. Viganoni, L. Commercio e Consumo nelle Città che Cambiano. Napoli, Città Medie, Spazi Esterni; Franco Angeli: Milan, Italy, 2019.

17. Sommella, R. Consumption and Retail in Urban Spaces: Studies on Italy and Catalonia. Bollett. Soc. Geogr. It. 2020, 14, 7-12. [CrossRef]

18. Groncow, J.; Warde, A. Ordinary Consumption; Routledge: London, UK, 2001.

19. Zukin, S. Prefazione. In Nuovi Scenari per l'Attrattività delle Città e dei Territori; Ingallina, P., Ed.; Franco Angeli: Milan, Italy, 2017; p. 9.

20. Leontidou, L.; Afouxenidis, A.; Kourliouros, E.; Marmaras, E. Infrastructure-related Urban Sprawl: Mega-events and Hybrid Peri-urban Landscapes in Southern Europe. In Urban Sprawl in Europe Landscapes, Land-Use Change E Policy; Couch, C., Leontidou, L., Petschel-Held, G., Eds.; Blackwell Publishing Ltd.: Oxford, UK, 2007; pp. 71-101.

21. Sommella, R.; D'Alessandro, L. Consumption and Demand for Places: A Reading through the Neapolitan Case. Bollett. Soc. Geogr. It. 2020, 14, 13-24. [CrossRef]

22. Dawson, J. Retail Geography, 3rd ed.; Routledge: Oxon, UK, 2013.

23. Findlay, A.; Sparks, L. Far from the 'Magic of the Mall': Retail (Change) in 'Other Places'. Scott. Geogr. J. $2012,128,24-41$. [CrossRef] 
24. Coe, N.; Wrigley, N. Towards New Economic Geographies of Retail Globalization. In The New Oxford Handbook of Economic Geography; Clark, G.L., Feldman, M.P., Gertler, M.S., Wójcik, D., Eds.; Oxford University Press: Oxford, UK, 2018 ; pp. $427-447$. [CrossRef]

25. D'Alessandro, L. Le politiche per il commercio: Scale, tempi, strumenti. In Commercio e Consumo nelle Città che Cambiano. Napoli, Città Medie, Spazi Esterni; Viganoni, L., Ed.; Franco Angeli: Milan, Italy, 2019; pp. 73-98.

26. Barata-Salgueiro, T.; Erkip, F. Retail planning and urban resilience-An introduction to the special issue. Cities 2014, 36, 107-111. [CrossRef]

27. Brunetta, G.; Salata, S. Mapping Urban Resilience for Spatial Planning-A First Attempt to Measure the Vulnerability of the System. Sustainability 2019, 11, 2331. [CrossRef]

28. Moraci, F.; Errigo, M.F.; Fazia, C.; Burgio, G.; Foresta, S. Making Less Vulnerable Cities: Resilience as a New Paradigm of Smart Planning. Sustainability 2018, 10, 755. [CrossRef]

29. Cachinho, H.; Salgueiro, T.B. Os sistemas comerciais urbanos em tempos de turbulência: Vulnerabilidades e níveis de resiliência. Finisterra 2016, 51, 89-109. [CrossRef]

30. Berry, B. Commercial Structure and Commercial Blight: Retail Patterns and Progresses in the City of Chicago; University of Chicago: Chicago, IL, USA, 1963.

31. Whysall, P. Managing decline in inner city retail centres: From case study to conceptualization. Local Econ. 2011, 26, 3-17. [CrossRef]

32. Bromley, R.D.F.; Thomas, C.J. The Retail Revolution, the Carless Shopper and Disadvantage. Trans. Inst. Br. Geogr. 1993, 18, 222-236. [CrossRef]

33. Fernandes, J.R.; Chamusca, P. Urban policies, planning and retail resilience. Cities 2014, 36, 170-177. [CrossRef]

34. Cachinho, H. Consumerscapes and the resilience assessment of urban retail systems. Cities 2014, 36, 135. [CrossRef]

35. Weichselgartner, J.; Kelman, I. Geographies of resilience: Challenges and opportunities of a descriptive concept. Prog. Hum. Geogr. 2015, 39, 249-267. [CrossRef]

36. Stumpp, E.M. New in town? On resilience and "Resilient Cities". Cities 2013, 32, 164-166. [CrossRef]

37. Moreno, C.; Allam, Z.; Chabaud, D.; Gall, C.; Pratlong, F. Introducing the "15-Minute City": Sustainability, Resilience and Place Identity in Future Post-Pandemic Cities. Smart Cities 2021, 4, 93-111. [CrossRef]

38. Barata-Salgueiro, T. The Resilience of Urban Retail Areas. In Retail Planning for the Resilient City. Consumption and Urban Regeneration; Barata-Salgueiro, T., Cachinho, H., Eds.; Centro de Estudos Geográficos: Lisbon, Portugal, 2011 ; p. 30.

39. Barata-Salgueiro, T.; Guimarães, P. Public Policy for Sustainability and Retail Resilience in Lisbon City Center. Sustainability 2020, 12, 9433. [CrossRef]

40. Dolega, L.; Celińska-Janowicz, D. Retail resilience: A theoretical framework for understanding town centre dynamics. Stud. Reg. Lokal 2015, 2, 8-31. [CrossRef]

41. Wrigley, N.; Dolega, L. Resilience, fragility, and adaptation: New evidence on the performance of UK high streets during global economic crisis and its policy implications. Environ. Plan. A Econ. Space 2011, 43, 2337-2363. [CrossRef]

42. Sommella, R. Sostenibilità urbana e città mediterranee. In Sviluppo Sostenibile a Scala Regionale; Menegatti, B., Tinacci Mossello, M., Zerbi, M.C., Eds.; Pàtron: Bologna, Italy, 2000; p. 660.

43. Leontidou, L. The Mediterranean City in Transition: Social Change and Urban Development; Cambridge University Press: Cambridge, UK, 1990.

44. Wrigley, N. Retail Geographies. In International Encyclopedia of Human Geography; Kitchin, R., Thrift, N., Eds.; Elsevier: London, UK, 2009; pp. 398-405. [CrossRef]

45. Leontidou, L. Repolarization of the Mediterranean: Spanish and Greek cities in neo-liberal Europe. Eur. Plan. Stud. 1995, 3, 155-172. [CrossRef]

46. Leontidou, L. Spaces of Risk, Spaces of Citizenship and Limits of the 'Urban' in European. In Proceedings of the Conference Lectured at the Symposium "(In)Visible Cities. Spaces of Hope, Spaces of Citizenship", Centre of Contemporary Culture of Barcelona, Barcelona, Spain, 25-27 July 2003; Available online: http:/ / www.cccb.org/rcs_gene/spaces_risk.pdf (accessed on 20 March 2021).

47. Othengrafen, F.; Cotella, G.; Papaioannou, A.; Tulumello, S. Socio-political and socio-spatial impacts of the crisis in European cities and regions. In Cities in Crisis: Socio-Spatial Impacts of the Economic Crisis in Southern European Cities; Knieling, J., Othengrafen, F., Eds.; Routledge: London, UK, 2016; p. 27.

48. D'Alessandro, L. Le città mediterranee tra autenticità e ibridazioni. Civiltà del Mediterraneo 2018, $29,185$.

49. Comune di Napoli (Municipality of Naples). La Struttura Demografica della Popolazione Residente nella Città di Napoli; Comune di Napoli: Naples, Italy, 2017. Available online: https://www.comune.napoli.it/flex/cm/pages/ServeBLOB.php/L/IT/IDPagina/ 34362 (accessed on 20 March 2021).

50. Comune di Napoli (Municipality of Naples). Rapporto UrBes Comunale di Napoli 2013; Comune di Napoli: Naples, Italy, 2014. Available online: http://www.comune.napoli.it/flex/cm/pages/ServeBLOB.php/L/IT/IDPagina/27920ouremphasis (accessed on 20 March 2021).

51. Ministero dello Sviluppo Economico (Ministry of Economic Development). Rapporto sul Sistema Distributivo Anno 2019; Ministero dello Sviluppo Economico: Rome, Italy, 2019. Available online: http:/ /osservatoriocommercio.sviluppoeconomico.gov.it/ Archivio_Rapporti/Rapporto_2019_web.pdf (accessed on 20 March 2021). 
52. Associazione Studi e Ricerche per il Mezzogiorno (Study and Research Association for Southern Italy). La Nuova Distribuzione Commerciale nel Mezzogiorno; Giannini Editore: Naples, Italy, 2007; Available online: https:/ /www.sr-m.it/wp-content/uploads / woocommerce_uploads/2015/09/ricerca_gdo.pdf (accessed on 20 March 2021).

53. Vona, R. La media distribuzione alimentare: Il nuovo commercio di prossimità. In Commercio, Consumo e Città. Quaderno di Lavoro; Viganoni, L., Ed.; Franco Angeli: Milan, Italy, 2017; pp. 143-149.

54. Ministero dello Sviluppo Economico (Ministry of Economic Development). Rapporto sul Sistema Distributivo Anno 2010; Ministero dello Sviluppo Economico: Rome, Italy, 2010. Available online: http://osservatoriocommercio.sviluppoeconomico.gov.it/ Archivio_Rapporti/Rapporto_2010Web.pdf (accessed on 20 March 2021).

55. Comune di Napoli (Municipality of Naples). Variante al Piano Regolatore Generale. Centro Storico, Zona Orientale, Zona Nordoccidentale; Comune di Napoli, Assessorato alla Vivibilità: Naples, Italy, 1999.

56. Comune di Napoli (Municipality of Naples). Relazione alla Variante al Piano Regolatore Generale. Centro Storico, Zona Orientale, Zona Nord-Occidentale; Comune di Napoli: Naples, Italy, 2004. Available online: https://www.comune.napoli.it/flex/cm/pages/ ServeBLOB.php/L/IT/IDPagina/1025 (accessed on 20 March 2021).

57. Della Lucia, M.; Trunfio, M. The role of the private actor in cultural regeneration: Hybridizing cultural heritage with creativity in the city. Cities 2018, 82, 35-44. [CrossRef]

58. Coppola, P.; Sommella, R.; Viganoni, L. Tra immagine e mercato. In La Forma e i Desideri. Saggi Geografici su Napoli e la Sua Area Metropolitana; Coppola, P., Ed.; Edizioni Scientifiche Italiane: Naples, Italy, 1997; pp. 235-251.

59. Sommella, R. Las «lentas» transformaciones de los espacios centrales de Nápoles. In La Cuestión del Centro, el Centro en Cuestión; Martínez i Rigol, S., Ed.; Milenio: Lleida, Spain, 2009; pp. 43-57.

60. D’Alessandro, L. Comercio en el centro y consumo de centro en Nápoles. In La Cuestión del Centro, el Centro en Cuestión; Martínez i Rigol, S., Ed.; Milenio: Lleida, Spain, 2009; pp. 105-117.

61. D'Alessandro, L.; Sommella, L.; Viganoni, L. Film-Induced Tourism, City-Branding and Place-Based Image: The Cityscape of Naples between Authenticity and Conflicts. Almatourism 2015, 6, 180-194. [CrossRef]

62. Comune di Napoli (Municipality of Naples). Grande Progetto "Centro Storico di Napoli, Valorizzazione del Sito Unesco"; Comune di Napoli: Naples, Italy, 2012. Available online: https:/ /www.comune.napoli.it/flex/cm/pages/ServeBLOB.php/L/IT/IDPagina/ 20994 (accessed on 20 March 2021).

63. Laino, G.; Lepore, D. Napoli: Una risposta alla crisi del governo urbano. In Le Agende Urbane delle Città Italiane. Secondo Rapporto sulle Cittàdi Urban@it; Pasqui, G., Briata, P., Fedeli, V., Eds.; Il Mulino: Bologna, Italy, 2017; pp. 143-159.

64. Sommella, R. Il territorio della ricerca: Fuori e dentro Napoli. In Commercio e Consumo nelle Città che Cambiano. Napoli, Città Medie, Spazi Esterni; Viganoni, L., Ed.; Franco Angeli: Milan, Italy, 2019; p. 67.

65. D'Alessandro, L. Il commercio su aree pubbliche tra degrado e riqualificazione: Napoli e i suoi mercati. Geotema 2009, 38, 58-63.

66. D'Alessandro, L. Attività Commerciali e Spazi Urbani. Per un Approccio Geografico al Centro Storico di Napoli; Guida: Naples, Italy, 2008; pp. 191-261.

67. Comune di Napoli (Municipality of Naples). Il Piano di Gestione del Sito UNESCO "Centro Storico di Napoli"; Comune di Napoli: Naples, Italy, 2011. Available online: https://www.comune.napoli.it/flex/cm/pages/ServeBLOB.php/L/IT/IDPagina/24103 (accessed on 20 March 2021).

68. Amendola, G. Tra Dedalo e Icaro. La Nuova Domanda di Città; Laterza: Roma-Bari, Italy, 2010.

69. D'Alessandro, L.; Martínez-Rigol, S. Consumando spazi centrali e notti urbane: Micro-geografie dei giovani a Barcellona e a Napoli. Bollett. Soc. Geogr. It. 2018, 14, 163-176. [CrossRef]

70. Comune di Napoli (Municipality of Naples). Map on the "Boundary of Historic Centre of Naples": World Heritage Site and Buffer Zone; Comune di Napoli: Naples, Italy, 2011. Available online: https://www.comune.napoli.it/flex/cm/pages/ServeBLOB.php/L/ IT / IDPagina/24103 (accessed on 20 March 2021).

71. D'Alessandro, L.; Salaris, A. Retail as an Instrument for the Revitalization of City Center: Considerations from Two Italian Medium-sized Cities. In Retail Planning for the Resilient City. Consumption and Urban Regeneration; Barata-Salgueiro, T., Cachinho, H., Eds.; Centro de Estudos Geográficos: Lisbon, Portugal, 2011; pp. 299-315.

72. Cozzi, T. Lockdown Fatale, La Repubblica Napoli, 19 May 2020. Available online: https://ricerca.repubblica.it/repubblica/ archivio/repubblica/2020/05/19/lockdown-fatale-tarallo-decide-di-chiudereNapoli02.html (accessed on 20 March 2021).

73. D'Alessandro, L. Micro-geografie di un'icona simbolica del commercio napoletano: Via Toledo tra mutamenti e contese. In Commercio e Consumo nelle Città che Cambiano. Napoli, Città Medie, Spazi Esterni; Viganoni, L., Ed.; Franco Angeli: Milan, Italy, 2019; pp. 289-314.

74. Bridge, G.; Dowling, R. Microgeographies of Retailing and Gentrification. Aust. Geogr. 2001, 32, 93-107. [CrossRef]

75. Cachinho, H. Avenida da Liberdade: From the Burgeoisie Promenade to the Showcase of International Capital. In City, Retail and Consumption; D'Alessandro, L., Ed.; Università degli Studi di Napoli “L'Orientale”: Naples, Italy, 2015; pp. 35-47.

76. D'Alessandro, L.; Sommella, R.; Viganoni, L. Atmospheres of and in Geography. In Atmosphere/Atmospheres: Testing A New Paradigm; Griffero, T., Moretti, G., Eds.; Mimesis International: Milan, Italy, 2018; pp. 31-45.

77. Martínez-Rigol, S. Can we talk about the retail gentrification. In L'Apporto della Geografia tra Rivoluzioni e Riforme; Salvatori, F., Ed.; A.Ge.I: Roma, Italy, 2019; pp. 2365-2373. 